\title{
Endophytic fungi associated with soybean plants and their antagonistic activity against Rhizoctonia solani
}

\author{
Nashwa Sallam ${ }^{1 *}$ DD, Esmat F. Ali' ${ }^{2,3}$, Mohamed A. A. Seleim ${ }^{4}$ and Hadeel M. M. Khalil Bagy ${ }^{1}$
}

\begin{abstract}
Background: Fungal endophytes produce many secondary metabolites that can reduce root rot diseases. Soybean is a particularly important crop worldwide. Endophytic fungi can be isolated, identified, and incorporated into sustainable agriculture for the biological control of many diseases.

Results: The aim of this study was to isolate some endophytic fungi for controlling the most important diseases of soybean plants and to study the mechanisms underlying this biocontrol regarding the suppression of pathogens. Ten endophytic fungi were isolated from soybean plants. Among them, the 3 fungi isolates that exhibited a high percentage of antagonistic activity against Rhizoctonia solani, the causal pathogen of root rot disease of soybean plants, were identified as Trichoderma longibrachiatum S12, T. asperellum S11, and T. atroviride PHYTAT7. The 3 fungi isolates had the ability to produce pectinase and chitinase and to solubilize phosphors. Moreover, they produced siderophores and indole acetic acid (IAA), which have a strong effect on the growth of the plants. The 3 isolates reduced disease severity by 64,60 , and $55 \%$, respectively than the infected control.
\end{abstract}

Conclusion: The results suggest that certain endophytic fungi associated with soybean plants have potential for the management of root rot diseases in soybean. Moreover, these isolates can be considered as having a growthpromoting effect in soybean plants.

Keyword: Endophytic fungi, Root rot, Soybean, Trichoderma spp. biocontrol

\section{Background}

Endophytes are microorganisms that live in the intercellular space of healthy plant tissues without causing any disease in the plants (Abo-Elyousr et al. 2014a). They also supply nutrients to the host, stimulate plant resistance to pathogens, cold, and drought, and promote plant growth by secreting hormones or supplying nutrients to their host plant (Suryanarayanan et al. 2012). Nair and Padmavathy (2014) mentioned that the symbiosis between microorganisms and plants is well known. Plants protect and feed the endophytes, which in response

\footnotetext{
* Correspondence: Nashwasallam@aun.edu.eg

'Department of Plant Pathology, Faculty of Agriculture, Assiut University, Assiut 71526, Egypt

Full list of author information is available at the end of the article
}

produce bioactive substances that enhance the growth and resistance of plants in the environment.

Soybean (Glycine max L.) is a leguminous plant of the Fabaceae family that is commonly found in many locations worldwide (Chowdhury et al. 2016). Nutritionally, soybean comprises $45 \%$ of protein and $18 \%$ of oil; thus, it is also known as a miracle crop. Diseases such as root rot, brown spot, soybean rust, downy mildew, and stem blot have been a major problem and cause losses in soybean production in many countries. Rhizoctonia solani is well known and widely dispersed in roots, plant debris, and soil, causing major diseases in a diverse range of hosts, including root rot in soybean plants (Surbhi et al. 2020). Fungicide application is the main method used for the control of such diseases. However, the use of fungicides is currently forbidden in many countries and

\section{Springer Open}

(ㅇ The Author(s). 2021 Open Access This article is licensed under a Creative Commons Attribution 4.0 International License, which permits use, sharing, adaptation, distribution and reproduction in any medium or format, as long as you give appropriate credit to the original author(s) and the source, provide a link to the Creative Commons licence, and indicate if changes were made. The images or other third party material in this article are included in the article's Creative Commons licence, unless indicated otherwise in a credit line to the material. If material is not included in the article's Creative Commons licence and your intended use is not permitted by statutory regulation or exceeds the permitted use, you will need to obtain permission directly from the copyright holder. To view a copy of this licence, visit http://creativecommons.org/licenses/by/4.0/. 
other methods for controlling of this disease are preferred, e.g., biological control and cultural practices (Arastehfar et al. 2019).

Traditional control methods have been suggested for root rot, such as the development of resistant cultivars and short rotation and culture practices; however, these methods are not always successful as Rhizoctonia spp. can remain for a long time in the soil via infested plant debris. Recently, several studies focused on alternative biological methods for the control of plant diseases that are characterized as being environmentally friendly, long lasting, and effective (Sallam et al. 2019). The use of beneficial microorganisms has been regarded as a hopeful method for the management of soil diseases (Fenta et al. 2019). Many beneficial microbes, such as Pseudomonas putida, Bacteriophages, Trichoderma spp., Paenibacillus macerans, P. fluorescens, Streptomyces spp., Enterobacter spp., Acinetobacter spp., and Bacillus spp., have been reported as efficient biocontrol agents against Rhizoctonia spp. (Sharma et al. 2017). Studies have focused on the mycoparasitic and antagonistic ability of isolates of Trichoderma to decrease the incidence of the diseases caused by plant pathogens (Abo-Elyousr et al. 2014b).

Therefore, the aim of this study was to isolate endophytic Trichoderma spp. from soybean plants and characterize their antagonistic activity against the causal pathogen of root rot disease of soybean. As well, their effect on disease reduction in pot experiments was studied.

\section{Methods}

\section{Source of the causal pathogen of soybean root rot}

The highly pathogenic isolates of Rhizoctonia solani used in this study were previously isolated and tested for pathogenicity by (Sallam Nashwa et al. 2008) who identified the isolates using the morphological features of mycelia, as described by Barnett and Hunter (1986). Pure fungal isolates were then grown on potato dextrose agar (PDA) slants at $25 \pm 2{ }^{\circ} \mathrm{C}$, then kept in a refrigerator at 4 ${ }^{\circ} \mathrm{C}$ for further studies.

\section{Isolation of endophyte fungi from soybean plants}

Healthy roots of soybean plants were collected, washed with tap water, and cut into small pieces, which were then surface sterilized in $2 \%$ sodium hypochlorite for 3 min and $70 \%$ ethanol for $3 \mathrm{~min}$, washed with sterile distilled water 3 times, and left to dry in a laminar flow chamber. The pieces were transferred to a Petri dish containing PDA medium and incubated at $27 \pm 2{ }^{\circ} \mathrm{C}$ for 10 days. Pure cultures were transferred onto PDA slants.

\section{Antagonistic capability of various endophytic fungi} isolates against Rhizoctonia solani

The five tested endophytic fungi isolates were grown on PDA medium and incubated for 5 days at $28{ }^{\circ} \mathrm{C}$ for use as inocula. PDA Petri plates ( $9 \mathrm{~cm}$ in diameter) were inoculated at $3 \mathrm{~cm}$ from the edge with disks of $R$. solani $(5 \mathrm{~mm}$ in diameter), followed by inoculation with the tested fungi on opposite sides of $R$. solani. Four replicates were used for each treatment. The control treatment consisted in plates with $R$. solani alone, without the inoculation of endophytic fungi. The plates were incubated for 7 days at $28{ }^{\circ} \mathrm{C}$. When the growth of the pathogen was covered, the plate in control treatment in the linear growth of the tested pathogen was recorded in the treatments fungi (Zein El-Abdean et al. 2013). The percentage of mycelial growth inhibition was calculated using the following formula: percentage of mycelial growth inhibition $=[T-F / T]$ $\times 100$, where $T$ is the mycelia growth in the control and $F$ is the mycelia growth in the tested isolate. The antagonistic fungi that afforded a high percentage of mycelial growth reduction were identified using a $28 \mathrm{~S}$ rRNA molecular method.

\section{Identification of Trichoderma spp. using polymerase chain reaction nucleotide sequencing (PCR-Seq)}

Three isolates were used in this study. The nuclear rDNA region spanning the ITS1 ITS2 regions was used for the first amplification, which was performed in a total reaction volume of $50 \mu \mathrm{l}$ including the following reagents: PCR buffer $(10 \mathrm{mM}$ Tris- $\mathrm{HCl}, \mathrm{pH} 8.3,50 \mathrm{mM}$ $\mathrm{KCl}, 1.5 \mathrm{mM} \mathrm{MgCl}_{2}$, and $0.01 \%$ gelatin), $200 \mu \mathrm{M}$ of each deoxyribonucleotide triphosphate, $0.4 \mu \mathrm{M}$ of each primer with $10 \mu \mathrm{l}$ of the template DNA solution, and $1 \mathrm{U}$ of Tth DNA polymerase (Toyobo). The PCR mixture was overlaid with $30 \mu \mathrm{l}$ of mineral oil. The following thermal cycling was performed on a thermal cycler (PC700; ASTEC): an initial denaturing step at $95{ }^{\circ} \mathrm{C}$ for 2 min; 30 cycles of $30 \mathrm{~s}$ at $72{ }^{\circ} \mathrm{C}$ for extension; and a final extension cycle of $7 \mathrm{~min}$ at $72{ }^{\circ} \mathrm{C}$. One microliter of the first amplification mixture was used for the second amplification using the nested primer set ITS1 (White et al. 1990) and P3. The components of the reaction mixture and the thermal cycling conditions used for the second amplification were the same as those used for the first one. The PCR products from the second amplification were subjected to preparative electrophoresis in 1.5\% agarose gels in Tris acetate EDTA (TAE) buffer. All amplifications yielded a single visible DNA product. The DNA product band was excised from the ethidiumbromide-stained gel and purified using a JETSORB kit according to the manufacturer's protocol. Direct sequencing of PCR products was performed on an Applied Biosystems 373A sequencer using a PRISM 
Dye Terminator Cycle Sequencing kit (Applied Biosystems) according to the manufacturer's protocol and using the ITS1 and ITS2 primers (White et al. 1990). The nucleotide sequence data of the ITS2 and ITS2 regions were subjected to pairwise alignment via the method of Lipman and Pearson (1985) using the program GENETYX-MAC (Software Development).

\section{Evaluation of the antagonistic effect of fungi under greenhouse conditions}

The inoculum was prepared in bottles containing barley grain medium using disks $(5 \mathrm{~mm})$ of $R$. solani isolates. The bottles containing barley medium were autoclaved at $121{ }^{\circ} \mathrm{C}$ and $1.5 \mathrm{~kg} / \mathrm{cm}^{2}$ for $20 \mathrm{~min}$ before inoculation with the pathogen. After inoculation, the bottles were incubated at $25 \pm 2{ }^{\circ} \mathrm{C}$ for 15 days. For soil infestation, $R$. solani barley grains were mixed with sterilized soil at a concentration of $3 \%$. Four replicates were used for each tested isolate (5 seedlings/pot). Pot experiments were carried out to study the effects of the 3 selected antagonistic fungi, for controlling the root rot incidence in soybean plants. Seeds of the Giza 111cv. soybean cultivar were sown in $R$. solani-infested soils as described above (5 seeds/pot), and the antagonistic fungi were applied as a soil treatment by adding a $3 \%$ solution to pots 7 days after infestation with $R$. Solani. Untreated pots served as the control. At 30 days after sowing, root rot disease severity was recorded as described previously (Abo-Elyousr et al. 2014b). The experiments were arranged in a randomized complete block design with 4 replicates. Disease severity percentage (DS\%) was estimated as follows: $\mathrm{DS} \%=[\Sigma \mathrm{A} / \mathrm{A}(4 \mathrm{~T})] \times 100$
Where $A$ is the disease rating on each plant, $d$ max is the maximum disease rating possible, and $4 \mathrm{~T}$ is the total number of plants $(T)$ multiplied by the maximum discoloration grade 4. According to Dorrance et al. (2003), with slight modifications, the different degrees of disease in plants were classified into 4 categories: $0=$ no root rot; $1=1$ to $33 \%$ of roots with visible lesions or root rot; 2 = approximately 34 to $50 \%$ of the roots exhibited rot or damage; $3=51$ to $80 \%$ of the roots exhibited rot; and $4=$ pre-emergence damping-off and few if any roots.

\section{Depiction of secondary metabolites and antifungal activity of endophytic fungi Solubilization of minerals}

Phosphate solubilization Pikovskaya medium was used to test the phosphate-solubilizing ability of the fungi isolates by dissolution of precipitated tricalcium phosphate $\mathrm{Ca}_{3}\left(\mathrm{PO}_{4}\right)_{2}$. The fungi isolates were inoculated on the surface of PDA medium dried plates. The plates were incubated for 7 days at $28{ }^{\circ} \mathrm{C}$. The solubilization index (SI) was calculated according to Edi-Premono et al. (1996).

Zinc solubilization As reported by Saravanan et al. (2003, b), the zinc-solubilizing ability of the tested fungi was detected based on the dissolution of precipitated zinc oxide on agar medium. On the surface of dried plates, a pinpoint inoculation of the fungal isolates was performed. Plates were incubated for 7 days at $28{ }^{\circ} \mathrm{C}$. The SI was calculated as reported by Edi-Premono et al. (1996), as follows: ratio of the total diameter (colony diameter + halo zone diameter)/colony diameter.

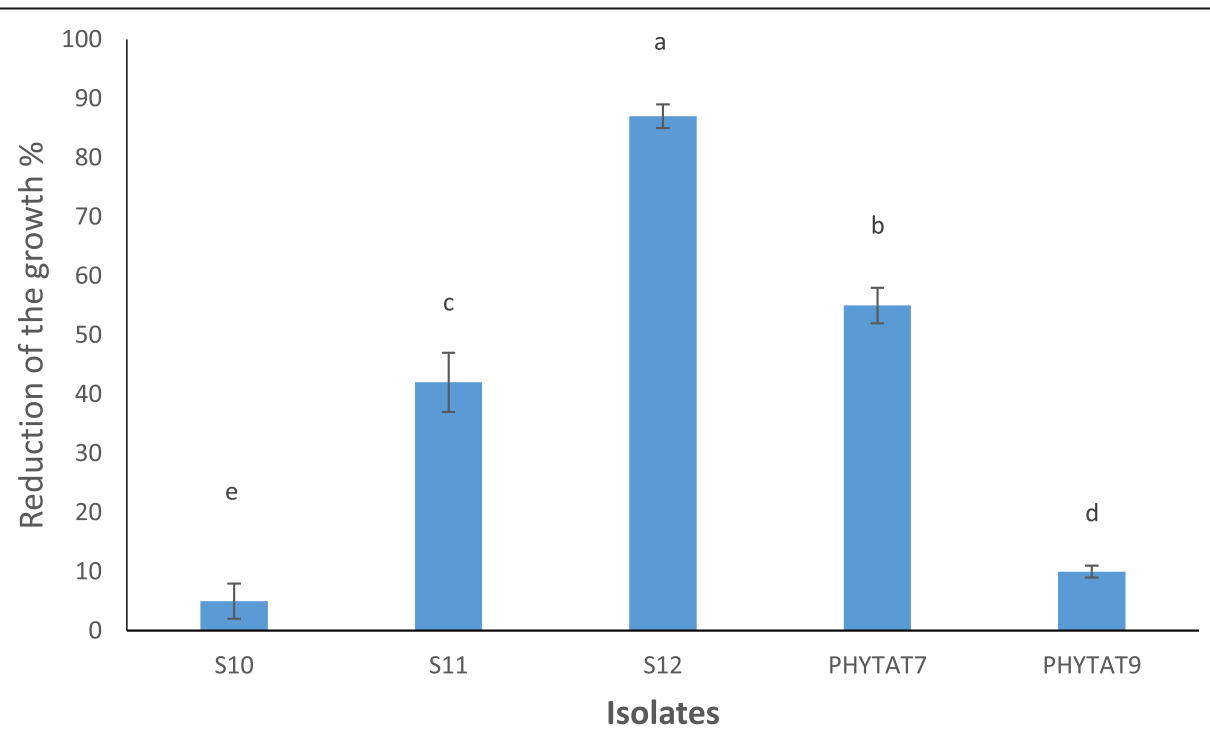

Fig. 1 In vitro study of the effect of five endophytic fungi isolates on the growth of Rhizoctonia solani. Values followed by the same letter are not significantly different, as determined by the LSD test $(P \leq 0.05)$ 




Fig. 2 Antagonistic activity of Trichoderma spp. isolates against Rhizoctonia solani in vitro

\section{Production of specific enzymes by the bioagent}

Using the disk plate method, the enzymatic activities of potent fungal bioagent were visualized on agar plates containing specific enzyme substrates (Acuna-Arguelles et al. 1995). These pathogens were screened for multiple enzymes, such as cellulases, pectinases, proteases, and amylase, on suitable substrates. The size of the clearing zone that developed around the colonies corresponded to the enzymatic activity.

Pectinase activity The tested fungal culture was inoculated on Czapek agar medium containing $2 \mathrm{NaNO}_{3} ; 1.0$ $\mathrm{K}_{2} \mathrm{HPO}_{4} ; 2$ peptone; $0.5 \mathrm{MgSO}_{4} 7 \mathrm{H}_{2} \mathrm{O} ; 0.5 \mathrm{KCl}$; and 20 agar $(\mathrm{g} / \mathrm{l})$ in $1000 \mathrm{ml}$ of distilled water at $\mathrm{pH} 6.8$ and enhanced with $1 \%$ citrus pectin as a substrate for pectinase.
The Petri dishes containing screening agar medium were incubated for $24 \mathrm{~h}$ at $30{ }^{\circ} \mathrm{C}$. One percent cetyl trimethyl ammonium bromide was added to observe the zone of clearance, which revealed the pectinase activity.

Cellulase activity Medium containing carboxy methyl cellulose $(\mathrm{CMC})(1 \% \mathrm{w} / \mathrm{v})$ was used to detect the cellulase activity. The Petri plates were incubated for $24 \mathrm{~h}$ at $27{ }^{\circ} \mathrm{C}$. After inoculation, the plates were screened for cellulase activity by flooding the plate with $1 \%$ Congo red solution for $15 \mathrm{~min}$, followed by de-staining using a $1 \mathrm{M} \mathrm{NaCl}$ solution for $15 \mathrm{~min}$. The clear zones around the growth of fungi indicated cellulase activity.

Amylase activity Medium containing starch $(1 \% \mathrm{w} / \mathrm{v})$ as a substrate was used to detect amylase activity. Plates were incubated at $27{ }^{\circ} \mathrm{C}$ for $24 \mathrm{~h}$. The clear zones around the fungal growth were observed by staining the plate with $50 \mathrm{mM}$ iodine.

Protease activity Medium containing casein (1\% w/v) as a substrate was used to test protease activity. Enzymatic activity was determined after the inoculation of the plate with the tested fungi. The formation of a clear zone around colonies after precipitation with $1 \mathrm{M} \mathrm{HCl}$ solution indicated protease activity (Rodarte et al. 2011).

\section{Production and assay of indole acetic acid}

The fungi strains were inoculated individually in 250 $\mathrm{ml}$ Erlenmeyer conical flasks containing $50 \mathrm{ml}$ of potato dextrose broth medium supplemented with $0.4 \%$ tryptophan, as a precursor. The inoculated flasks were then incubated in agitated conditions of 150 rpm for 7 days. After incubation, the fungal growth

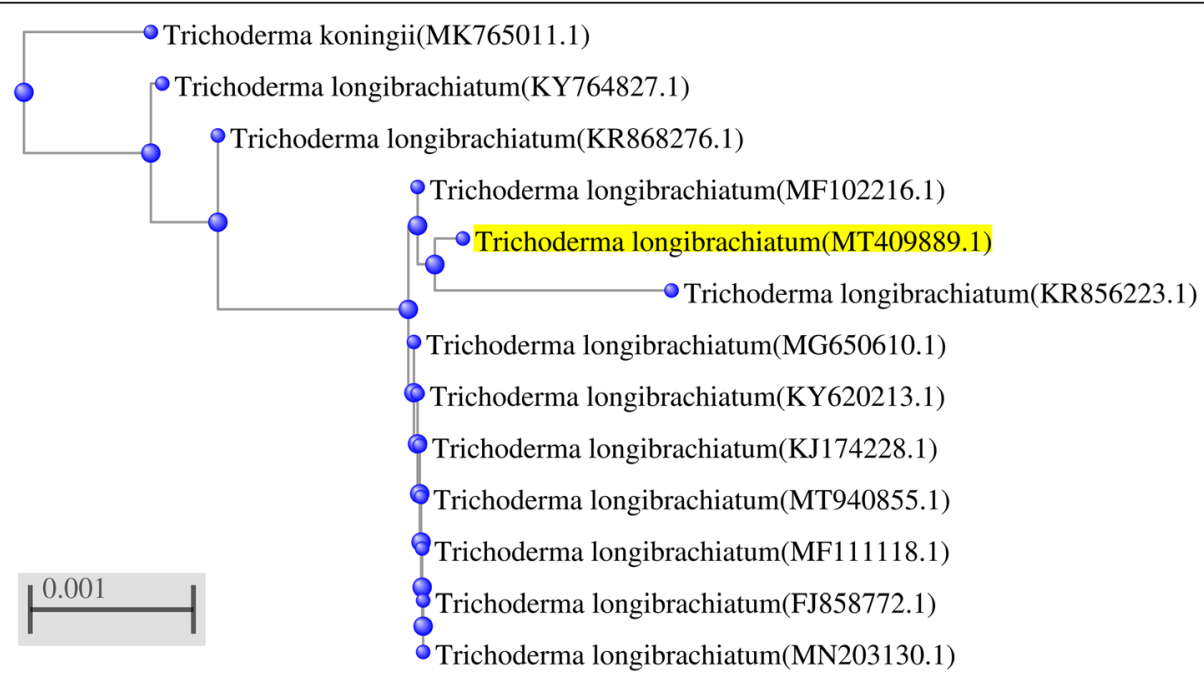

Fig. 3 Close homologs of Trichoderma longibrachiatum strain S12 (MT409889.1) shown in a phylogenic tree 
Table 1 Molecular characterization of S12, S11, and PHYTAT7 by ITS analysis

\begin{tabular}{|c|c|c|c|c|c|c|c|}
\hline Fungal isolates & Maximum score & Total score & Query cover & $E$ value & Percent identity & Most similar organism & GenBank accession no. \\
\hline$S 12$ & 1138 & 1138 & $95 \%$ & 0.0 & $98.46 \%$ & Trichoderma longibrachiatum & LT707585.1 \\
\hline S11 & 1059 & 1059 & $90 \%$ & 0.0 & 98.20 & T. asperellum & KR856220.1 \\
\hline PHYTATT & 994 & 994 & $96 \%$ & 0.0 & $100 \%$ & T. atroviride & MT604177.1 \\
\hline
\end{tabular}

was decanted by centrifugation at $10,000 \mathrm{rpm}$ for 10 min and the cell-free supernatants were used as sources of indole acetic acid (IAA). The reaction mixture consisted of $1 \mathrm{ml}$ of the cell-free supernatant and $2 \mathrm{ml}$ of the Salkowski reagent $(1 \mathrm{ml}$ of $0.5 \mathrm{M} \mathrm{FeCl}_{3}$ in $50 \mathrm{ml}$ of $35 \%$ perchloric acid). The mixture was then incubated at $28{ }^{\circ} \mathrm{C}$ for $30 \mathrm{~min}$. Quantification was performed calorimetrically at 530 $\mathrm{nm}$ by comparison to an IAA standard curve (Gordon and Paleg 1957).

\section{Qualitative estimation of siderophores}

The production of siderophores by fungi isolates was assayed via the plate assay method, as described by Schwyn and Neilands (1987). After growth, fungal isolates (a 5-mm disk of each isolate) were potted on Chrome Azurol S blue agar plates and incubated for 48 $\mathrm{h}$ at $28 \pm 2{ }^{\circ} \mathrm{C}$. The development of a yellow-orange zone around the colony was taken as a positive indication of siderophore production. The extent of siderophore biosynthesis was measured as the diameter of the colored zone (Alexander and Zeeberi 1991).

\section{Statistical analysis}

Data were subjected to statistical analysis using the MSTATC program of variance, and means were compared using the least significant difference (LSD) test at $P \leq 0.05$, as described by Gomes and Gomes (1984). The
LSD at $5 \%$ probability was used for testing the significance of the differences among the mean values of the tested treatments.

\section{Results}

Antagonistic activity of the endophytic fungi isolates against Rhizoctonia solani in vitro

Five isolates of endophytic fungi were first tested for their antagonistic capability against $R$. solani in vitro before identification. The results presented in Fig. 1 showed that 3 fungal isolates exhibited inhibition percentages that were $>80 \%$. Isolate S12 afforded the highest percentage of inhibition (87\%), followed by the isolate PHYTAT7 (55\%) and isolate S11 (42\%). Isolates PHYTAT9 and S10 yielded the lowest reduction of the pathogen. Based on these results, the three isolates were selected for subsequent experiments (Fig. 2a, b, and c).

\section{Identification of the antagonistic fungi isolates using $16 \mathrm{~S}$ rRNA gene sequencing}

Pure cultures of the 3 fungal isolates were molecularly characterized, using $16 \mathrm{~S}$ rRNA sequencing. Based on BLAST searches on the NCBI data libraries (Nucleotide Collection Database) for similarities of the 16S rRNA sequences, isolate S12 was the most similar to Trichoderma longibrachiatum (GenBank accession No. LT707585.1), with $98.46 \%$ identity and

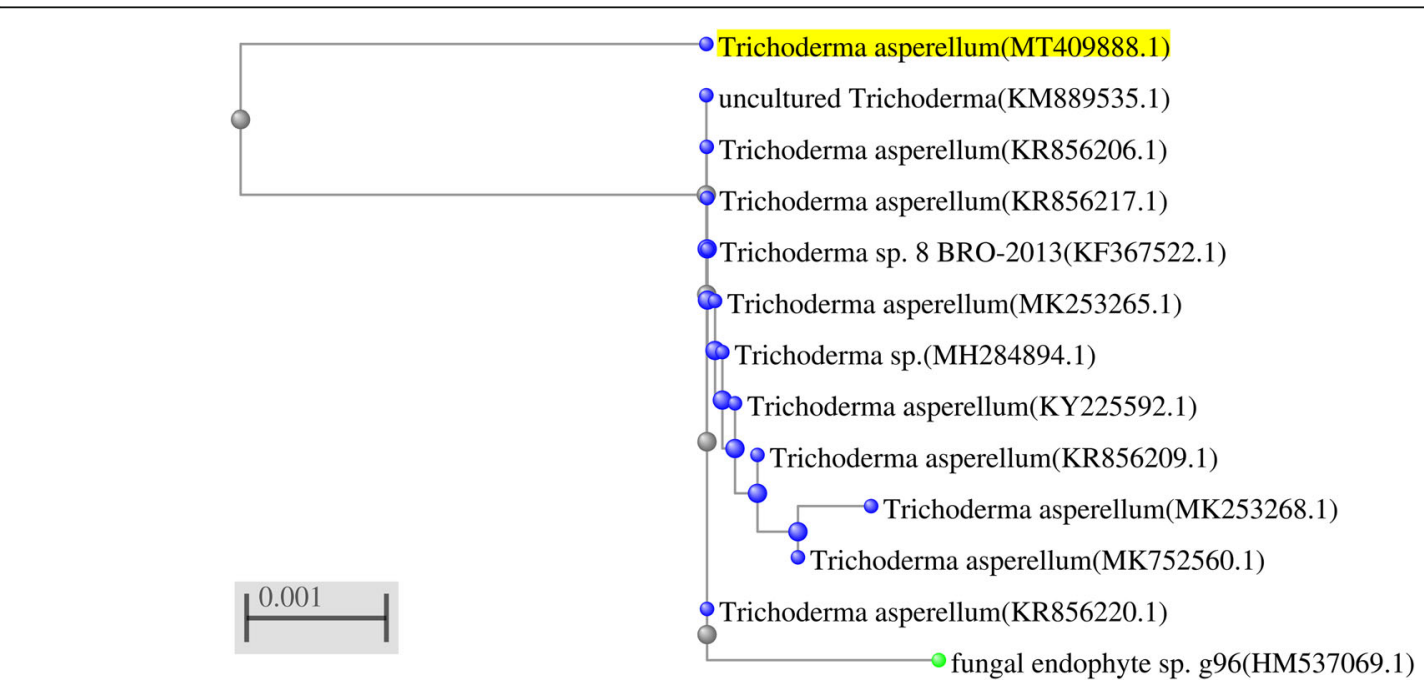

Fig. 4 Close homologs of Trichoderma asperellum strain S11 (MT409888.1) shown in a phylogenic tree 
95\% query coverage. The next closest homolog was the T. longibrachiatum isolate MIAE00828 (GenBank accession No. KM225906.1) (Fig. 3), whereas isolate S11 was identified as Trichoderma asperellum and was the most similar to the $T$. asperellum strain BHU-BOT-RYRL14 (GenBank accession No. KR856220.1) and Trichoderma asperellum strain BHU-BOT-RYRL11 (GenBank accession No. KR856217.1), respectively, (Table 1 and Fig. 4). In addition, the BLAST search showed that the highest match of isolate PHYTAT7 was the Trichoderma atroviride strain KABOFT6 (GenBank accession No. MT604177.1) with $100 \%$ sequence similarity (Table 1 and Fig. 5). The 16S rRNA sequences of isolates S12, S11, and PHYTAT7 were deposited within the

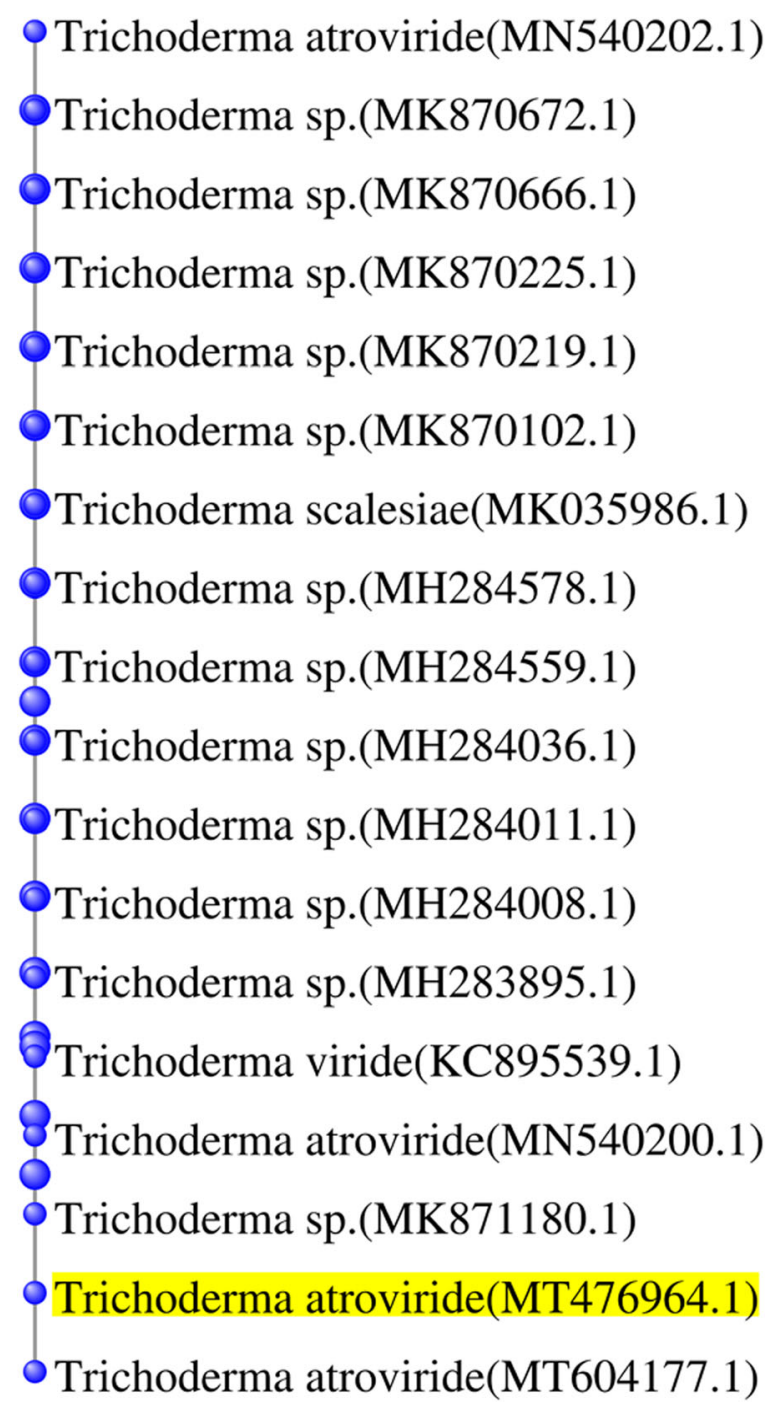

Fig. 5 Close homologs of Trichoderma atroviride isolate PHYTAT7 (MT476964.1) shown in a phylogenic tree
Table 2 In vivo study effect of three endophytic fungi isolates on growth of Rhizoctonia solani under greenhouse conditions

\begin{tabular}{lll}
\hline Fungal isolates & $\begin{array}{l}\text { Disease severity } \\
(\%)\end{array}$ & $\begin{array}{l}\text { Disease reduction } \\
\text { (\%) }\end{array}$ \\
\hline $\begin{array}{l}\text { Trichoderma longibrachiatum } \\
\text { S12 }\end{array}$ & $35^{\mathrm{c}}$ & 57.3 \\
T. asperellum S11 & $30^{\mathrm{d}}$ & 63.4 \\
T. atroviride PHYTAT7 & $42^{\mathrm{b}}$ & 48.8 \\
Infected control & $82^{\mathrm{a}}$ & 0
\end{tabular}

*Values in the same column, followed by the same letter are non-significantly different according to LSD test $(P=0.05)$

GenBank sequence database under the accession nos. MT409889.1, MT409888.1, and MT476964.1, respectively.

Evaluation of the antagonistic effect of fungi under greenhouse conditions

The results presented in Table 2 showed that all the tested isolates of Trichoderma spp. reduced disease severity significantly. The addition of treatments comprising $T$. asperellum (S11) afforded the highest disease reduction than other treatments. It abated disease by (63.4\%) compared to the infected control. T. longibrachiatum (S12) came second regarding the reduction of disease severity (57.3\%), whereas $T$. atroviride (PHYT AT7) caused the lowest reduction in disease severity.

In vitro study of the mode of action of the endophytic fungal pathogens Siderophore production

The results presented in Table 3 showed that all tested endophytic fungi isolates gave positive responses regarding the production of siderophores. Among the fungi isolates tested, S11 produced the maximum percentage of siderophores (2.3) compared to the control, followed by S12 and PHYT AT7, which afforded a siderophore production of 2.5 .

\section{Production of IAA}

The results presented in Table 3 showed that all fungal isolates tested for the ability to produce IAA yielded positive results. The highest production rate was observed at S11, followed by S12 and PHYTAT7.

Table 3 Production of siderophore and IAA, by the endophytic fungal pathogens

\begin{tabular}{lll}
\hline Fungal isolates & Siderophore (Halo $\mathbf{~ c m})$ & IAA $\mathbf{~ g} / \mathbf{m l}$ \\
\hline Trichoderma longibrachiatum S12 & $2.5^{\mathrm{b}}$ & $3.4^{\mathrm{b}}$ \\
T. asperellum S11 & $3.3^{\mathrm{a}}$ & $4.5^{\mathrm{a}}$ \\
T. atroviride PHYTAT7 & $2.5^{\mathrm{b}}$ & $3.4^{\mathrm{b}}$ \\
\hline
\end{tabular}

*Means followed by the same letter are not significantly different according to Duncan's multiple range tests at $5 \%$ 
Table 4 Solubilization phosphate index measurement of S11 and S12 and PHYTAT7 after 7 days at $28^{\circ} \mathrm{C}$

\begin{tabular}{|c|c|c|c|c|c|c|}
\hline \multirow[t]{2}{*}{ Fungal isolates } & \multicolumn{3}{|c|}{ Phosphate solubilization index (PSI) } & \multicolumn{3}{|c|}{ Zinc solubilization index (PSI) } \\
\hline & $\begin{array}{l}\text { Colony } \\
\text { diameter }(\mathrm{cm})\end{array}$ & $\begin{array}{l}\text { (Zone of } \\
\text { solubilization in } \\
\mathrm{cm}\end{array}$ & $\begin{array}{l}\text { Phosphate } \\
\text { solubilization index } \\
\text { (PSI) }\end{array}$ & $\begin{array}{l}\text { Colony } \\
\text { diameter }(\mathrm{cm})\end{array}$ & $\begin{array}{l}\text { (Zone of } \\
\text { solubilization in } \\
\mathrm{cm} \text { ) }\end{array}$ & $\begin{array}{l}\text { Zinc solubilization } \\
\text { index (PSI) }\end{array}$ \\
\hline $\begin{array}{l}\text { Trichoderma } \\
\text { longibrachiatum S12 }\end{array}$ & 4.3 & 5.5 & 2.27 & 3.5 & 3.9 & 2.10 \\
\hline T. asperellum S11 & 4.7 & 4.9 & 2.04 & 3.5 & 3.8 & 2.01 \\
\hline T. atroviride PHYTAT7 & 2.8 & 2.5 & 1.89 & 2.6 & 2.2 & 1.80 \\
\hline
\end{tabular}

\section{Zinc and phosphate solubilization by fungal isolates}

The zinc and phosphate solubilization ability of fungal isolates (S11, S12, and PHYTAT7) were tested in vitro. The data presented in Table 4 exhibited that S11 and S12 had positive effects on zinc solubilization and scored a strong solubilization index (SI) of (2.1), while PHYT AT7 scored a moderate SI of (1.8). Moreover, S11 and S12 had positive effects on phosphate solubilization, with an SI of (2.74), while the PHYTAT7 had an SI of (1.89).

\section{Production of lytic enzymes}

The data presented in Table 5 revealed that all tested isolates exhibited protease- and cellulase-producing ability and that they produced amylase and pectinase, with the exception of the isolate PHYTAT7, which did not produce the latter two enzymes.

\section{Discussion}

Rhizoctonia root rot of soybean is one of the most important diseases in the world. This disease is caused by Rhizoctonia solani (Kohn), which affects seed germination and seedling emergence, causing great losses in soybean yield (Abo-Elyousr et al. $2014 b)$. Five endophytic fungi were isolated from soybean plants. The results revealed that all the tested Trichoderma spp. isolates were able to inhibit the mycelial growth of the pathogen with different degrees of antagonistic capability. Obtained data indicated that $T$. asperellum afforded the strongest antagonistic effect against the pathogen, followed by other isolates. The results are in accordance with the data of Singh and Chand (2006). Trichoderma spp. are known to have a strong antifungal effect partly because of their production of extracellular chitinase, amylase, and protease enzymes, which hydrolyze the main constituent of the fungal cell wall (Abo-Elyousr et al., $2014 b)$. This can be explained in light of the results reported by Benhamou et al. (1998) who suggested that $T$. harzianum is affected through direct penetration of host hyphae. Trichoderma harzianum grows toward the hyphae of pathogenic fungi and degrades the cell walls of the pathogens via the activity of enzymes, which could be associated with physical penetration of the cell walls of the pathogens. Endophytes may stimulate plant growth and increase yield directly or indirectly (Khare et al. 2018).

The siderophores produced by fungi can repossess the limited iron, thus reducing its availability for the growth of phyto-pathogens. Thus, they promote plant growth indirectly (Alexander and Zeeberi 1991). Obtained results showed that the isolate $S 11$ produced the maximum percentage of siderophores, followed by $S 12$ and then PHYTAT7. These results agree with those reported by Rabbee et al. (2019), who found that Trichoderma spp. produce high concentrations of siderophores, which in turn inhibit fungal growth via deprivation of essential iron. Some endophytic fungi have the ability to synthesize IAA, which may explain the increase in the growth of some plants after their colonization with endophytic fungi (Shi et al. 2009). In the present study, the 3 isolates tested for the ability to produce IAA yielded positive results. These results agree with those of Palazzini et al. (2018), and Bereika et al. (2020). Chitinases are receiving increased attention because of their broad range of applications. Many of these chitinase-producing microorganisms have been used recently as an important biocontrol agent against fungal phytopathogens, by degrading the chitin component of the fungal cell wall (Nguyen et al. 2015). Obtained results agree with those reported by Myo et al. (2019).

In the present study, all isolates had ability to solubilize zinc and phosphate with different degrees.

Table 5 Production of amylase, protease, chitinase, and pectinase enzymes by the fungal pathogens

\begin{tabular}{|c|c|c|c|c|}
\hline \multirow[t]{2}{*}{ Fungal isolates } & \multicolumn{4}{|c|}{ Lysis enzymes } \\
\hline & Amylase & Protease & Cellulase & Pectinase \\
\hline Trichoderma longibrachiatum S12 & + & + & + & + \\
\hline T. asperellum S11 & + & + & + & + \\
\hline T. atroviride PHYTAT7 & - & + & + & - \\
\hline
\end{tabular}

$(+)=$ positive effects $(-)=$ negative effects 
These agree with those reported by Wani et al. (2007). Altomare et al. (1999) found that a strain of T. harzianum produces many chemicals that solubilize rock phosphate, $\mathrm{Zn}, \mathrm{Mn}^{4+}, \mathrm{Fe}^{3+}$, and $\mathrm{Cu}^{2+}$, increases iron availability, and enhances iron uptake in vitro. Wakatsuki (1995) reported that microbes are potential alternatives that could cater plant zinc requirements by solubilizing the complex zinc in soil. Lytic enzyme production by pathogens has been postulated to play an important role in the biological control of pathogens (Myo et al. 2019). In the present study, the ability of fungal isolates to produce lytic enzymes was tested. All tested pathogens yielded production of lytic enzymes, which act as inducers of plant resistance. Lytic enzyme production by pathogens has been reported by Myo et al. (2019). Bhale and Rajkonda (2012) reported that the activities of extracellular hydrolytic enzymes exhibited different rates according to Trichoderma species, such as the cellulase and pectinase produced by a fungal biocontrol agent, and are responsible for the inhibition of plant pathogenic fungi.

\section{Conclusion}

The results suggest that Trichoderma spp. can be used for controlling rhizoctonia root rot in soybean plants caused by $R$. solani under greenhouse conditions. Enzymes successfully suppressed the fungal pathogen in vitro and in vivo. Further research is needed to identify an appropriate formulation and approve the application of a new strain for the control of the wide range of plant diseases.

\section{Abbreviations}

IAA: Indole acetic acid; S11: T. asperellum; S11: T. longibrachiatum; PHYTAT7: T. atroviride; SI: Solubilization index; LSD: Least significant difference; PDA: Potato dextrose agar; ZSB: Zinc solubilizing bacterial

\section{Acknowledgements}

Authors are thankful to Taif University Researchers Supporting Project number (TURSP-2020/65), Taif University.

\section{Authors' contributions}

All authors contributed equally in the manuscript.

N.M. S. suggested the idea of the work and contributed to data curation and their validation as well as writing original draft. EFA contributed to the formal analysis of the data., M.H. and M.S. contributed to the reviewing and editing the manuscript. All authors reviewed and approved the final version of the manuscript.

\section{Funding}

Authors are thankful to Taif University Researchers Supporting Project number (TURSP-2020/65), Taif University, Taif, Saudi Arabia, for providing the financial support and research facilities.

Availability of data and materials Not applicable

\section{Declarations}

Ethics approval and consent to participate

This manuscript is in accordance with the guide for authors available on the journal's website. Also, this work has not been published previously and is approved by all authors and host authorities.

\section{Consent for publication}

Not applicable.

\section{Competing interests}

No potential conflict of interest was reported by the authors.

\section{Author details}

'Department of Plant Pathology, Faculty of Agriculture, Assiut University, Assiut 71526, Egypt. ${ }^{2}$ Department of Biology, College of Science, Taif University, P.O. Box 11099, Taif 21944, Saudi Arabia. ${ }^{3}$ Department of Horticulture (Floriculture), Faculty of Agriculture, Assuit University, Assiut, Egypt. ${ }^{4}$ Agricultural Botany Department, Faculty of Agriculture, Al-Azhar University (Assiut Branch), Assiut 71524, Egypt.

Received: 19 November 2020 Accepted: 10 March 2021

Published online: 19 March 2021

\section{References}

Abo-Elyousr KAM, Sobhy IIA, Abdel-Rahim IR (2014a) Isolation of Trichoderma and evaluation their antagonistic potentiality against Alternaria porri. J Phytopathol 162(9):567-574. https://doi.org/10.1111/jph.12228

Abo-Elyousr KAM, Zein El-Abdean W, Hassan MHA, El-Sheakh MM (2014b) Enhance suppressive effect of compost on soybean Rhizoctonia root rot by soil treatment with Trichoderma harzianum. J Plant Physiol Pathol 2(02):2. https://doi.org/10.4172/2329-955X.1000122

Acuña-Argüelles ME, Gutierrez-Rojas M, Viniegra-González G, Favela-Torres E (1995) Production and properties of three pectinolytic activities produced by Aspergillus niger in submerged and solidstate fermentation. Appl Microbiol Biotechnol 43(5):808-814. https://doi.org/10.1007/BF02431912

Alexander BD, Zeeberi DA (1991) Use of chromazurol S to evaluate siderophore production by rhizosphere bacteria. Biol Fertil Soils 2:39-54

Altomare C, Norvell WA, Björkman T, Harman GE (1999) Solubilization of phosphates and micronutrients by the plant- growth promoting and biocontrol fungus Trichoderma harzianum Rifai 1295-22. Appl Environ Microbiol 65(7):2926-2933. https://doi.org/10.1128/AEM.65.7.2926-2933.1999

Arastehfar A, Cornelia L, Rocio G, Farnaz D, Macit I, Teun B, Toni G, David SP (2019) The quiet and underappreciated rise of drug-resistant invasive fungal pathogens. J Fungi 6(3):138. https://doi.org/10.3390/jof6030138

Barnett HL, Hunter BB (1986) Illustrated genera of imperfect fungi, 4th edn. Macmillan Publishing Co., New York

Benhamou N, Kloepper JW, Tuzun S (1998) Induction of resistance against Fusarium wilt of tomato by combination of chitosan with an endophytic bacterial strain: ultrastructure and cytochemistry of the host response. Planta 204(2):153-168. https://doi.org/10.1007/s004250050242

Bereika FFM, Sallam NMA, Alamri SAM, Abo-Elyousr KAM, Hashem M, Mostafa YS (2020) Approving the biocontrol strategy of potato wilt caused by Ralstonia solanacearum on field scale using Enterobacter cloacae PS14 and Trichoderma asperellum T34. Egypt J Biol Pest Control 30:1-13

Bhale UN, Rajkonda JN (2012) Enzymatic activity of Trichoderma species. Novus Nat Sci Res 1:4

Chowdhury JA, Karim MA, Khaliq QA, Solaiman ARM, Ahmed JU (2016) Screening of soybean (Glycine max I.) genotypes under water stress condition. Bangladesh J Agril Res 41:441-450

Dorrance AE, Kleinhenz MD, Mcclure SA, Tuttle NT (2003) Temperature, moisture, and seed treatment effects on Rhizoctonia solani root rot of soybean. Plant Dis 87(5):533-538. https://doi.org/10.1094/PDIS.2003.87.5.533

Edi-Premono M, Moawad AM, Vlek PLG (1996) Effect of phosphate solubilizing pseudomonas putida on growth of maize and its survival in the rhizosphere. Indonesian J Crop Sci 11:13-23

Fenta L, Habtamu M, Tsegaye G (2019) Biocontrol potential of trichoderma and yeast against post-harvest fruit fungal diseases: a review. World News Nat Sci 27:153-173

Gomez KA, Gomez AA (1984) Statistical procedures for agricultural research. Wiley, NY 
Gordon SA, Paleg LG (1957) Observations on the quantitative determination of indoleacetic acid. Physiol Plant 10(1):39-47. https://doi.org/10.1111/j.1399-3 054.1957.tb07608.x

Khare E, Mishra J, Arora NK (2018) Multifaceted interactions between endophytes and plant: developments and prospects. Front Microbiol 9:2732. https://doi. org/10.3389/fmicb.2018.02732

Lipman DJ, Pearson WR (1985) Rapid and sensitive protein similarity searches. Science 227(4693):1435-1441. https://doi.org/10.1126/science.2983426

Myo EM, Liu B, Ma J, Shi L, Jiang M, Zhang K, Ge B (2019) Evaluation of Bacillus velezensis NKG-2 for bio-control activities against fungal diseases and potential plant growth promotion. Biol Control 134:23-31. https://doi.org/1 0.1016/j.biocontrol.2019.03.017

Nair DN, Padmavathy S (2014) Impact of endophytic microorganisms on plants, environment and humans. Scient World J 250693

Nguyen HQ, Quyen DT, Nguyen SLT, Van Hanh VU (2015) An extracellular antifungal chitinase from Lecanicillium lecanii: purification, properties, and application in biocontrol against plant pathogenic fungi. Turk J Biol 39:6-14. https://doi.org/10.3906/biy-1402-28

Palazzini J, Roncallo P, Cantoro R, Chiotta M, Yerkovich N, Palacios S, Echenique V, Torres A, Ramirez M, Karlovsky P, Chulze S (2018) Biocontrol of Fusarium graminearums ensus tricto, reduction of deoxynivalenol accumulation and phytohormone induction by two selected antagonists. Toxins 10:88. doi: https://doi.org/10.3390/toxins10020088.

Rabbee MF, Ali MS, Choi J, Hwang BS, Jeong SC, Baek KH (2019) Bacillus velezensis: a valuable member of bioactive molecules within plant microbiomes. Molecules 24(6):1046-1059. https://doi.org/10.3390/ molecules24061046

Rodarte MP, Dias DR, Vilela DM, Schwan RF (2011) Proteolytic activities of bacteria, yeasts and filamentous fungi isolated from coffee fruit (Coffea arabica L.). Acta Scient Agronomy 33:457-464

Sallam NMA, Eraky AM, Sallam A (2019) Effect of Trichoderma spp. on fusarium wilt disease of tomato. Mol Biol Rep 46(4):4463-4470. https://doi.org/10.1 007/s11033-019-04901-9

Sallam Nashwa A, Abo-Elyousr KAM, Hassan MA (2008) Evaluation of Trichoderma species as biocontrol agents for damping-off and wilt diseases of Phaseolus vulgaris $L$ and efficacy of suggested formula. Egypt J Phytopathol 36:81-93

Saravanan VS, Subramoniam SR, Raj SA (2003) Assessing in vitro solubilization potential of different zinc solubilizing bacterial (ZSB) isolates. Braz J Microbiol 35:121-125

Schwyn B, Neilands JB (1987) Universal chemical assay for the detection and determination of siderophores. Anal Biochem 160(1):47-56. https://doi.org/1 0.1016/0003-2697(87)90612-9

Sharma M, Tarafdar A, Ghosh R, Gopalakrishanan S (2017) Biological control as a tool for eco-friendly management of plant pathogens. In: Adhya T, Mishra B, Annapurna K, Verma D, Kumar U (eds) Advances in soil microbiology: recent trends and future prospects. Microorganisms for Sustainability, pp 153-188. https://doi.org/10.1007/978-981-10-7380-9_8

Shi Y, Lou K, Li C (2009) Promotion of plant growth by phytohormone-producing endophytic microbes of sugar beet. Biol Fertil Soils 45(6):645-653. https://doi. org/10.1007/s00374-009-0376-9

Singh S, Chand H (2006) Screening of bioagents against root rot of mung bean caused by Rhizoctonia solani. Mol Plant Microbe Interact 18:710-721

Surbhi K, Krishna PS, Narendra KS, Aravind T (2020) Assessment of genetic diversity among soybean genotypes differing in response to aerial blight (Rhizoctonia solani Kuhn) using SSR markers. J Phytopathol 169:37-44. https://doi.org/10.1111/jph.12956

Suryanarayanan TS, Thirunavukkarasu N, Govindarajulu MB, Gopalan V (2012) Fungal endophytes: an untapped source of biocatalysts. Fungal Divers 54(1): 19-30. https://doi.org/10.1007/s13225-012-0168-7

Wakatsuki T (1995) Metal oxidoreduction by microbial cells. J Food Ind Microbiol 14(2):169-177. https://doi.org/10.1007/BF01569900

Wani PA, Khan MS, Zaidi A (2007) Chromium reduction, plant growth promoting potentials and metal solubilization by Bacillus sp. isolated from alluvial soil. Curr Microbiol 54(3):237-243. https://doi.org/10.1007/s00284-006-0451-5

White TJ, Bruns TD, Lee S, Taylor J (1990) Amplification and direct sequencing of fungal ribosomal genes for phylogenetics. In: Innis MA, Gelfrand DH, Sninsky JJ, White TJ (eds) PCR protocols, pp 315-322

Zein El-Abdean W, Abo-Elyousr KAM, Hassan MHA, El-Sheikh MM (2013) Molecular characterization of Rhizoctonia solani isolates the incitant of soybean root rot. Arch Phytopathol Plant Protect 46(9):1108-1117. https:// doi.org/10.1080/03235408.2012.759407

\section{Publisher's Note}

Springer Nature remains neutral with regard to jurisdictional claims in published maps and institutional affiliations.

\section{Submit your manuscript to a SpringerOpen ${ }^{\circ}$ journal and benefit from:}

- Convenient online submission

- Rigorous peer review

- Open access: articles freely available online

- High visibility within the field

- Retaining the copyright to your article

Submit your next manuscript at $\boldsymbol{\nabla}$ springeropen.com 